\title{
ART AS COUNTERPUBLICS? MODES OF RESISTANCE IN CONTEMPORARY CULTURE'
}

\begin{abstract}
This article discusses the art projects, which fulfill the function of counterpublics, which I understand, following Nancy Fraser, Alexander Kluge and Oskar Negt, as a critique of the political institutions, which also undermines the public/private divide. Some recent artistic productions in Poland have generated such forms of critique and resistance, allowing voices and demands of various oppressed minorities not only to be represented, but also to enter and initiate public debates and transform the modes of contestation. They imply another resistance and critique, which overcome the heroic modes of articulation, thus enacting the weak, marginalized and ordinary as political agency.
\end{abstract}

Keywords: art, feminist art, resistance, critique, counterpublics

In neoliberal capitalism conformity became the central value. Resistance, contestation and struggle can be discussed in multiple ways, they can be staged and performed, but the actual acts of insubordination happen extremely rarely. Why is that? Perhaps because in precarious and unstable labor market, everyone quickly learns to stay in line. Perhaps the lack of organized workplaces and thus also a lack of organized labour movement makes cultural producers less willing to take risks and therefore also stabilizes everyone? The modes of production typical for our time projects, residencies and other short-term involvements also do not allow practicing resistance, for before terminating one assignment, the cultural producer knows they will have to be elsewhere soon, probably in some other city, country or even continent - thus starting a bigger conflict would just be too complicated. ${ }^{2}$ Today's artists are forced to begin a project in one place, investigate and research, build an innovative narrative, possibly using new technique or artistic format, and puff!, they have

1 Research for this article was made possible through the grant of the National Science Centre, Poland (NCN 2016/23/B/HS2/01338).

2 The "projectariat" was depicted in the book: K. Szreder, ABC Projektariatu, Fundacja Bęc Zmiana, Warszawa 2015. 
to go some place else. This kind of research/art residency travel sometimes happens several times in one year. The artist Zofia Kulik described it in an interview we did in 2009 , she called it "a system of (chess) pawns," as she was pushed from one place to another, incapable of experiencing the reception of her work, scattered between different places and cultures, forced to invent her art anew in every location. ${ }^{3}$ Due to this system of constant mobility of artists and projects and the commodified system of artistic production, artists and curators often withdraw potentially "controversial" elements of their works, replacing them with more acceptable content. But sometimes the mechanisms intended to limit or cancel artistic expression lead to resistance and public debate. This article follows acts of resistance in today's field of artistic production, mainly in Poland, and discusses them as characteristic for counterpublics, thus emphasizing the critical function of art as that making it genuinely "public". Among the discussed examples there are visual arts and theatre projects, as well as cases of "artivism", all leading to the conclusion, that public art can, and sometimes does, act as counterpublics, allowing marginalized and excluded voices, enhancing the debate and/or staging the dissent.

"Counterpublics" is a term originating in the critical reception of Jürgen Habermas's theory of the public sphere. ${ }^{4}$ Opposing the exclusions and limitations of this liberal vision of the public, Alexander Kluge and Oskar Negt wrote about the proletarian public spheres, which they called "counter public spheres." Nancy Fraser theorized the feminist counterpublics, emphasizing, how they always engage in a twofold opposition: to the existing power structures and the privileged groups. ${ }^{6}$ As I argue in this article, the artistic counterpublics - those opposing censorship, but also those who demand it, offer a (sometimes problematic) context to the issue of resistance in the field of artistic production. As it is shown further, resistance modes cannot be reduced to refusal and/or resignation, as it is sometimes assumed. They also appear as public debates, protests, performances, strikes and other modes of contestation, regardless the economic and political climate, most often actually caused by it. Some most fascinating acts of resistance actually begun in context of censorship or hate speech, thus proving, that the origins of resistance are not only always happy or innocent. Most of them also question or undermine the public/private divide.

Counterpublics, opposing the state apparatus, but also cultural and economic elites, have been perfect sites of resistance. In the formulation of Alexander Kluge and Oskar Negt, proletarian counterpublics are the public spheres of those who are always already foreclosed and marginalized. Classical theories of the public sphere, from Aristotle to Habermas, always focus on the privileged classes as agents of his-

Z. Kulik in conversation with E. Majewska, System Pionków, "Tygodnik Powszechny” 2009, no. 36.

J. Habermas, Structural Transformation of the Public Sphere, MIT Press, Cambridge, MA 1990.

A. Kluge, O. Negt, Public Sphere and Experience, Verso, London [1972] 2016.

N. Fraser, Rethinking the Public Sphere: A Contribution to the Critique of Actually Existing Democracy, "Social Text" 1990, no. 25/26; E. Majewska, Kontrpubliczności ludowe i feministyczne. Wczesna "Solidarność" i Czarne Protesty, IWKiP, Warszawa 2018. 
tory, limiting the participation in the debates on common matters to the privileged few, who were men, did not engage in labour and could afford the comfort of political reflection due to the labour of several precarized "others," who worked for their well being and needs. While doing that, the classical authors of political theory also exclude women and the popular classes, from the public sphere. The plebeian publics are not just omitted in the descriptions of the public sphere, they are also made invisible by the very construct of the European self, always autonomous and individual, always based, as Isabel Lorey rightly argues, on the precarization of some "others." Nancy Fraser depicted the feminist counterpublics as those enacting women's political agency, also invisible in most analyses of the public sphere; as being many and always undermining the public/private divide. In this article I discuss several recent art and theatre projects in Poland as counterpublics.

Important examples of such tendencies could be provided by many art institutions and galleries, but I believe that perhaps the most striking example was the performative theater piece, realized in 2018 by the team of Biennale Warszawa in collaboration with the Museum of Modern Art in Warsaw, Modern Slavery. In that piece the research concerning today's forms of slavery depicted the Ukrainian workers used as cheap/free labor force, provided by Polish criminal groups, in Warsaw restaurants. It was extraordinary, and yet the means of its display met all the criteria of a theatric presentation. ${ }^{8}$ A similar proximity of research and theatric expression was presented in another piece, at Teatr Powszechny in Warsaw, Michał Zadara's Sprawiedliwość (Justice). This piece produced a peculiar pact with the audience, somehow implying it in the quest for justice - it announced that the deportation and forced migration of some 13,000 of Jews from Poland in 1968 was a crime against humanity. Thus since crime against humanity has to be reported to the police, the audience was somehow implicated in the responsibility for further hiding the crime, if they did not report it. The piece - constructed as many criminal tv series, consisted in an office work of some 4 functionaries (perhaps prosecutors, perhaps workers of the state archives, maybe policemen or journalists - they were not defined). The piece was only 45 minutes long, and it was filled with detailed historical, social, journalistic and legal informations concerning the brutal events of the Polish March 1968, making it a breathtaking experience, an accusation and a crime, if one did not report... Altogether - this piece resisted on several levels - it resisted to forget, like the archive in Jacques Derrida's Archive Fever, it resisted to comply with the irresponsibility of the state, it resisted mere journalism, being a very well composed theater piece, and it resisted improvisation, at the same time being more interactive than the majority of participatory art project, since it installed a pact of historical and juridical responsibility on the audience. ${ }^{9}$ And it definitely built a counterpublics - allowing a frame-

7 See: I. Lorey, State of Insecurity, transl. by A. Derieg, Verso, London 2015. For the exclusion of plebeian public spheres as (supposedly) historically insignificant, see: J. Habermas, op. cit.

8 See: B. Frąckowiak, N. Sielewicz, Modern Slavery, MSN and Biennale Warszawa, 2018.

9 See: M. Zadara, Sprawiedliwość, Teatr Powszechny w Warszawie, 2018. 
work of justice and questions of responsibility to float in the conversations, thoughts and perhaps also actions of the audience. This was also one of the effects of the Modern Slavery experience, as it gave names of restaurants, bars and hotels, where the enslaved workers were supposed to be placed, and thus triggered guilt and perhaps action on the part of the audience as well. Yet - due to the precise solution presented in Sprawiedliwość, the burden of responsibility and doubt was perhaps harder to erase.

An important aspect of the vitality of the art world in Poland is the work art production performs today as a part of the public sphere, and more precisely - its work as part of the functioning counterpublics, announcing its critiques and subversions not only of the ruling government or state institutions, but also of the public/private divide, largely associated with (neoliberal) capitalism..$^{10}$ In this twofold opposition, to the current government and to the cultural and economic elite, artistic counterpublics assume the complex role of expressing the needs, critiques and desires of the most suppressed and invisible social actors, therefore acting as a space of expression of subaltern classes and groups. Public art, Rosalyn Deutsche argues, assumes its role by questioning the public/private divide, allowing the political aspects of gender, gentrification and other topics to appear in new, provocative ways, opening and fueling the sometimes non-existent public debate. ${ }^{11}$ Deutsche rightly argues that the merely decorative role sometimes assumed by art does not qualify as "public", only the questioning of existing political divisions does. Deutsche references Kluge and Negt and their ideas concerning the proletarian counter publics to make the point about the necessarily critical aspects of public art stronger. As such a contesting force, art is not only a result of contradictory forces but also itself causes further disagreements, thus provoking taming reactions from institutions and private agents. Following her argument, I would like to suggest that public art functions as such only when it acts as counterpublics, and most cases of resistance happen precisely there.

Artistic production has become one of the fields of the social that allows expressing the oppressed voices silenced, marginalized or excluded elsewhere. Since the feminist and participatory projects from the 1960s and 1970s, art and theatre directly engage in processes such as elections, discussions over state and private funding, city spaces or gender divisions, becoming a version of the agora. Many debates concerning political matters happen more vividly in art projects than in traditional political spaces and groups, media or universities. It is in the context of this oppositional role and the individual choices it entails, that art is often being produced, curated and exhibited to the public. Resistance can be caused and motivated by all aspects of artistic production or just some of them, but it usually never simply happens only on the level of what we tend to call individual choice. As it will be shown further, the concept of

10 R. Deutsche, Art and Public Space: Questions of Democracy, "Social Text" 1992, no. 33, pp. 34-53; E. Majewska, Sztuka jako pozór? Cenzura i inne paradoksy upolitycznienia kultury, Korporacja Ha!art, Kraków 2013; I. Kowalczyk, Uroki władzy. O władzy rozproszonej, ideologii i widzeniu, Galeria Miejska Arsenał, Poznań 2009.

11 R. Deutsche, op. cit. 
resistance is a paradoxical one, it demands a clear demonstration of the multiplicity of aspects of artistic production today and the plethora of socio-cultural and political factors, which contribute to it.

In this article I discuss the artists and curators as involved in a large constellation of sometimes conflicting needs, positions and interests: as acting in public sphere, creating multiple and sometimes conflicted counterpublics. It is in conflict and, therefore, in a position of resistance that the artists and curators work and take decisions. The art projects resist and enact a plethora of forces. They resist the existing "partitions of the sensible" (by entering their new strategies), they resist commodification and the instrumentalization of their work, they resist time and money pressures, undermine the public/private divide, just to mention a few. ${ }^{12}$

Michel Foucault famously observed that wherever there is control, there always is resistance. ${ }^{13} \mathrm{I}$ believe this observation is particularly important for any discussion of public art, including its functions as counterpublics. It allows understanding, in line with the arguments of Judith Butler, that the restrictions of artistic freedom, including censorship or other political limitations, are productive, they generate results, such as silencing or marginalization, as well as resistance and counterpublics. In her book The Excitable Speech, Butler argues for an understanding of censorship as a productive force. ${ }^{14} \mathrm{Her}$ analysis of hate speech and the possible reactions to it imply a Foucauldian understanding of control and regulation as formative force structuring subjects and societies by means of a ban or obligation, imposition of symbolic norms, which - incorporated in early socialization, sometimes become completely invisible. The cases of hate speech Butler discusses do not stop the targeted individuals from developing, they force them to act differently than they might want, sometimes they also cause pain, but sometimes they lead to emancipated, resistant expressions. Butler argues that the main purpose of hate speech is to block the attacked subject, to limit their ability to respond and impose on them a state of resignation and failure. This is structurally similar to censorship, in which the imposed limitations are expected to cause a similar sense of deprivation, guilt and eventually also resignation. In her analysis Butler shows however, that censorship and hate speech acts sometimes do not subsume the aimed goal of silencing the object of attack or regulation. Butler states that "When we claim to have been injured by language, what kind of claim do we make? We ascribe an agency to language, a power to injure, and position ourselves as the objects of its injurious trajectory." ${ }^{15}$ As we are linguistic beings, vulnerable to harm, censorship is called upon as means of protection. Yet, it in turn limits the forms of expression, and therefore repeats the function usually subsumed by the

12 J. Rancière, The Politics of Aesthetics: The Division of the Sensible, transl. by G. Rockhill, Continuum, London 2004.

13 M. Foucault, Discipline and Punish: The Birth of the Prison, Vintage Books - Random House, New York 1995.

14 J. Butler, Excitable Speech, Routledge, London-New York 1997.

15 Ibidem, p. 1. 
hate speech. In the example of Toni Morrison's discussion of hate speech as censorship a parallel between the two is presented. ${ }^{16}$ Butler also discusses the examples of feminist and queer pornography being challenged and censored. Censorship has the same aim, as discrimination - it is supposed to leave the censored person or group disempowered. Yet, each of them can also cause resistance - as the cases of Golgota Picnic and Dorota Nieznalska, and so many art and theatre pieces show. However some acts of censorship do not generate new art forms, but resistance, in form of a public debate, solidarity actions etc. However, it needs to be stressed, that in order to claim the possibility of resistance, and thus the effectivity of counterpublics, also in art, we need to understand, that not all censorship is successful, or at least - that its results might be mixed, including resistance as well as silencing.

The other author I would like to reference here, in the context of the complexities of the art field, is Denis Diderot. In Paradox of the Actor, Diderot built a compelling vision of the contradictions inherent in artistic production, contrasting the moral insufficiencies and controversies often found in the biographies of artists or at least attributed to them and the sublime aesthetic experiences, which they build for the public. ${ }^{17}$ These contradictions, often imaginary, account for the complexity of the making of art and its work in the process of "new partition of the sensible" as Jacques Rancière has argued. ${ }^{18}$ From the contradictions inherent in the artistic process, or the social more generally, we tend to choose those positions, actions and arguments, which fit to the brave, heroic, sometimes macho model of resistance. Our understanding of contestation has been shaped according to the cultural masculinity, with its priority of active over passive, visible over invisible, heroic over weak, etc. The modes of resistance enacted in recent art projects, often alternate this scenario, emphasizing the modes of persistence, sisterhood or weakness, thus building up the modes of subjectivity atypical for patriarchal culture - those of the excluded, marginalized and oppressed. Art acting as counterpublics expresses existing social conflicts, undermining one of the main divisions allowing inequalities to happen: the public/ private divide. The ability art has in becoming counterpublics can be enacted in multiple forms, it often takes place when various forms of censorship appear. It does not always lead to success in overcoming the censor, but it often enacts critical public debate, sometimes - public demonstrations, new artworks or other actions.

In artistic and curatorial practice censorship and resistance take multiple forms, and they are often invisible. They can appear on the level of programming an event or exhibition, in the process of applying for funding and of spending the money; in negotiations with or within the art institution, they can take the form of preventive cuts, letters and media scandals, they can also appear after an art piece has been presented. They can also be result of the process of negotiating a contract. In some cases it is

16 Ibidem, p. 9.

17 D. Diderot, Paradoxe sur le comédien, Hermann, Paris 1996.

18 J. Rancière, op. cit. 
the act of censorship (refusal to stage a theatre piece, cancelling an exhibition, etc.), which lead to counterpublics. I would even argue, against the generally progressive notion of counterpublics presented by Nancy Fraser, that the radical right-wing protests against some theater or art pieces also constitute elements of counterpublics. ${ }^{19}$ In all such cases however it is the art piece, which initiates the counterpublics - the protests or censoring agency are always already triggered by the artistic production.

In March 2009, in an act of preventive censorship, the director of the Centre for Contemporary Art "Łaźnia" in Gdańsk canceled an entire exhibition, before its opening to the public. The artist, Alina Żemojdzin, was to present a collection of cosmetics, supposedly made of human fat, a work which had received excellent reviews at the local Academy of Art. The local media described the project as "scandalizing", leading to a heated discussion between the local cultural authorities. ${ }^{20}$ Surprisingly, the director of the CCA, Jadwiga Charzyńska, decided not to present the exhibition at all, therefore committing a strong act of censorship. Some directors of art venues in Poland had previously censored particular works, but no one had cancelled an entire exhibition. Charzyńska justified her decision by saying that the artist was "running in the railway station with a jar, asking, where she could find some human fat.".21

According to the Gdańsk Art Academy professor and leading Polish artist Grzegorz Klaman, the cancellation was an illegitimate decision. Activists of the Indeks 73 anti-censorship network declared support for the artist and claimed that there was no legal ground for the cancellation of Żemojdzin's exhibition. Charzyńska declared that it was "the scandal" that she feared most, though she also made vague references to Polish law. ${ }^{22}$ However what the artist did does not violate any Polish law. Running in the station and shouting would not suffice to bring her to the court of justice. Clearly the media scandal was enough to stop the exhibition. In this case, unfortunately, resistance did not succeed in bringing back the exhibition, however the artist was supported in her claim to defend her art from the accusations of genocide or otherwise criminal actions, and a debate sparkled over the limits of artistic production, as well as over the duties and responsibilities of the directors of public art galleries.

Another case of resistance, this time with some extravagantly radical implications, took place during the Theatre Festival "Malta" in Poznan in June 2014. The piece under attack was Rodrigo Garcia's Golgota Picnic, depicting Jesus Christ as a contemporary man, undergoing an existential crisis, just as any human can, and written in the style of Allen Ginsberg. This refreshing text was banned after a series

19 I believe that such could be the understanding of the public protests against the piece Klatwa, staged in Teatr Powszechny in Warsaw in 2016.

20 D. Karaś, Idealny krem z ludzkiego tluszczu, "Gazeta Wyborcza”, 6.03.2009, http://wyborcza. pl/1,75398,6350018,Idealny_krem_z_ludzkiego_tluszczu.html (accessed 27.05.2019).

21 Ł. Rudziński, Skandal w Łaźni, czyli o pokazie, który się nie odbyt, Trójmiasto.pl, 10.03.2009, https:// kultura.trojmiasto.pl/Skandal-w-Lazni-czyli-o-pokazie-ktory-sie-nie-odbyl-n31925.html (accessed 25.05.2019).

22 See: ibidem. 
of interventions. First came the objections of the "concerned public": a group called Youngsters Crusade launched a petition, immediately signed by 40,000 people, even though the signatures could have been fake. ${ }^{23}$ Then came objections from the Polish Catholic Bishops, the local authorities and the Ministry of Culture. All these actions brought reactions from the director of the Malta festival, Michał Merczyński. At first, he opposed the cancellation of the piece and quoted the Polish Constitution, which, in chapter 73, guarantees the freedom of cultural expression and participation in culture. ${ }^{24}$ On the $16^{\text {th }}$ June 2014 a meeting was called by the Mayor of Poznan, Ryszard Grobelny, where Merczyński was informed that a demonstration of supposedly 50,000 opponents of the piece, including football fans, would take place on the day of the opening of Golgota Picnic. The local chief of Police declared his incapacity to prevent violence and assure the safety of the show. Shortly after this meeting Merczyński cancelled Golgota Picnic, citing safety concerns. It is interesting to note however, that in other situations, such as football events or street demonstrations, the Police assures safety by bringing support from other regions, if needed. Also the Polish law does not give the Police any right to refuse to "serve and protect."

On the $22^{\text {th }}$ June a meeting of cultural activists and artists resulted in an action plan: to present Golgota Picnic in as many cultural venues as possible, in solidarity with the director, actors and crew. The action was called Golgota Picnic - do it yourself, and it constitutes one of the most interesting examples of resistance in the recent art practice in Poland. The plan suggested that actors, activists and the public should engage in: 1) staging and/or readings of the text of the piece in public institutions or squares; 2) organizing meetings and discussions about the piece in public galleries, libraries and other venues and 3) signing petitions and otherwise supporting the demand for freedom of cultural activities. It is clear, that already on the level of planning, this plan was assuming the role of art as counterpublics, where the voices of minorities (especially: non-believers, artists, queers) were supposed not only to appear in public, but also negotiate the borders between public and private.

The results were splendid - actions took place in 13 cities, some 50 events related to Golgota Picnic were hosted by public theaters, museums, galleries, public squares, and libraries. Some of them were interrupted by representatives of ultra conservative political groups or media, some not. The public debate was growing when something unexpected happened - for the first time in many years several Catholic priests declared that they found a censored piece enriching and interesting and a young nationalist expressed his concern about freedom of expression. The cultural public responded positively to these efforts of staging Golgota Picnic.

The response to the decision of the director of Malta Festival to cancel the production was predominantly critical. The director defended his decision by insisting that

\footnotetext{
23 A. Adamiecka-Sitek, I. Kurz (eds.), Piknik Golgota Polska. Sztuka - religia - demokracja, Wydawnictwo Krytyki Politycznej, Warszawa 2015.

24 Ibidem, p. 67.
} 
after surviving one dramatic incident with casualties in a theatre some years before (decorations suddenly fell, killing one actor), he could not allow anything similar to happen again. The well-known art critics and theater producers, Monika Muskała and Agata Adamiecka-Sitek, were among the fiercest critics of the director's decision, emphasizing the state's obligation to guarantee freedom of expression and explaining that although controversy often occurs in culture, it should not lead to censorship. Muskała called Merczyński's reaction "passivity," "giving in to pressure" and "capitulation. ${ }^{25}$

The reasons for the censorship of Golgota Picnic were quite different from those given by Jadwiga Charzyńska. Both decisions were regarded, however, as cowardly and dangerous for freedom of artistic expression in Poland. Most artistic and activist circles condemned both cancellations and accused both directors of giving in to pressure and preventive censorship. While most descriptions of this cases focus on critique of censorship, I would like to emphasize, that the 50 events of re-staging $\mathrm{Gol}$ gota Picnic all over Poland, the nation-wide debate concerning the piece itself, the discussion concerning the freedom of expression, and the solidarity actions all over the country build up to be the unprecedented mobilization of support and resistance, which followed a very unheroic, ordinary methods and strategic choices. It is thus that it should not only be summarized as counterpublics, but also - as an expression of the resistance of the weak rather, than a heroic gesture typical for the classical modes of political action.

The (in)famous 2001 case of Dorota Nieznalska, who was not only censored, but also prosecuted for "hurting religious feelings" (Article 96 of the Polish Penal Code), caused a different debate, predominantly focused on the quality of the artist's work. Her work Passion, was criticized as "bad art" by both those who prosecuted the artist and those who defended her. ${ }^{26}$ It was common to reduce the installation to only the "cross with genitals". In fact the work was a light-box in the shape of a cross with equal arms, depicting the male genitals. It was accompanied by videos of men working out in a gym. The whole work was condemning the supposedly artificial ideal of a muscled masculine body, thus suggesting the possibility for some "true" or "genuine" values, something that should have actually pleased conservative cultural critics. The artist was sentenced to (suspended) 6 months of prison after a trial in which the accusers openly claimed that they did not see the piece, the sentence was replaced by a few weeks of public service. The artist was acquitted on appeal in 2009, when experts were called and the accusations were proved groundless. However, for the 9 years this took, the artist was not exhibited and could not leave Poland because she was facing criminal charges. The public debate was in large part a promotion of the ultra-right wing party (LPR) and the conservatism of the Polish cultural elites.

25 See: M. Muskała, “Odwoływanie spektakli to najgorsze z rozwiązań”, in: A. Adamiecka-Sitek, I. Kurz (eds.), Piknik Golgota Polska ...

26 See: A. Araszkiewicz, Sprawa Nieznalskiej a proces Gorgonowej, “Obieg Art Magazine” 2006, http:// archiwum-obieg.u-jazdowski.pl/teksty/5848 (accessed 24.04.2018). 
Only a few critics, such as Agata Araszkiewicz or Łukasz Skąpski, openly supported Nieznalska in the beginning of the case. In 2003, while the legal case was still ongoing, the feminist demonstration held in Warsaw every year for the $8^{\text {th }}$ of March (International Women's Day) was dedicated to supporting Nieznalska and criticizing censorship in Poland. The organizers asked the artist if she could make a poster for it. Nieznalska was very hesitant, explaining that since the start of the case she had been suffering from depression. She changed her mind several times and finally decided to design the poster, which was used as the invitation to the demonstration. The poster was very dramatic and played on the innocent/guilty distinction applied to the (body of) artist, the human/deity's body on a cross and the general notion of art. This act of public support and of granting some visibility to the artist, whose work in the long years of her process was almost not exhibited, was another case of art inspiring a counterpublics, this time with the active involvement of a progressive social movement, namely the feminists.

During the court case against her, Nieznalska was not only depressed, she had difficulties finding any gallerist that would show her work. Nieznalska's work was also reduced to the scandal and she was declared a "bad artist," although almost no one knew the work itself. The later work she did however, particularly that focusing on oppression and violence, including the poster for the women's demonstration in 2003, proves that she found ways of transforming the painful experiences into convincing artwork. In a piece made in 2011, Re-construction of the 16 Dec. 1981, Nieznalska referenced the first days of state violence directed at innocent people right after the introduction of Martial Law in Poland on the 13 December 1981. The remake of the metal gate of the Shipyard of Gdansk, where the independent workers union "Solidarność" was born, after it was hit by tanks, references the violence of the state in a twofold way: as a historical reconstruction, but also as a reference to the artist's own story of being unjustly persecuted for the artwork. This example shows how an analysis of censorship solely as a negative, depriving force, does not allow to approach the often brave and creative ways artists and other censored individuals react to censorship. It also shows, how resistance can proceed by means of persistence and willfulness rather, than heroic gestures of disagreement. Nieznalska's case, running for 9 years, was a constant reminder of the limitation freedom of expression and a pretext for an ongoing debate concerning artistic freedoms.

As I am trying to show, the art becomes counterpublics in many different ways, not necessarily intentionally. The Passion of Dorota Nieznalska was not intended to become a national scandal. The artist emphasized her interest in discussing values, not her own radical choices, her work was a critique of reification, not an act of announcing some scandalous new values. Yet - it was presented and later also accused of radical intention, of contesting religion etc. The Golgota Picnic was a case of a text and theater piece, which inspired some hundreds or even thousands of people in several cities in Poland to spontaneous staging, thus becoming a genuine case of "emancipated public", but also - a counterpublic understood as an alternative public sphere 
to that, where censorship prevailed. The case of Alina Żemojdzin's work on the other hand contributed tremendously to the discussions of two important topics: the limits of artistic freedom, but also - I believe, more importantly, that of the responsibilities of the directors of public art institutions.

What happens as a side process of such counterpublics, but in the end subsumes the role of their central element, are new forms of resistance. Resistance is usually happening in the intersection of the individual and the social. It is therefore perhaps important to ask, whether resistance can be discussed within a dialectic perspective, where the subjective and particular decision is always already intertwined in the social and opposed to other perspectives and obligations than those formed by individual? Is it not always in a context and in some relations (artist-the public, the institution-the artist, institution-public, media-artist etc.) that resistance takes place? And if yes, is it not necessary to see it not just as situated, but also as intrinsically connected with the other parts of the cultural field and also as something that has multifold preceding acts and repercussions? Isn't the artistic resistance also involved in a larger chain of actions? And as such - isn't it, at least in some cases, acting as a form of a public, one alternative to that limited by censorship? The nature of the artistic counterpublics is, I would like to claim, collective, but it is enacted in a series of interactions, thus sublating the individual/collective divide, as well as undermining that of public/private. According to Kluge and Negt, as well as Fraser, such is the nature of counterpublics.

If we subscribe to such contextualized and collective vision of artistic resistance, it becomes really hard to follow the individualist logic of art production and censorship, assuming, that oppositional activity can at all be individual. It almost never is. From Antigone - who, as Bonnie Honig clearly proves, acted not on her own, but in a sororal, anti-patriarchal pact with her sister, Ismene, down to today's artists and activists - we never are merely individuals. ${ }^{27}$ There are always others, networks, groups, kins, friends, students, co-workers to support and sustain our battles. We are not alone.

A feminist, in-depth critique of the liberal model of subjectivity was presented by Carole Pateman, among others. In her analysis of the "fraternal social contract" Pateman discusses the autonomous self of today's liberal democracies as always based on the exclusions of women and the colonized, therefore artificially separated from those responsible for the formation and survival of those democracies. ${ }^{28}$ In the context of her analysis, later supplemented by critics of precarisation, such as Isabel Lorey, and theories of the subject, such as that presented in Dividuum by Gerald Raunig, we need to perhaps rethink the notion of the individual, and while still as-

27 B. Honig, Antigone, Interrupted, Cambridge University Press, Cambridge 2013.

28 C. Pateman, The Disorder of Women, Polity Press, Cambridge 1989. 
signing legal responsibility to a person, perhaps provide a contextual analysis of their decisions and acts. ${ }^{29}$

The question of individual agency structurally mirrors not solely the Marxist critique of the liberal economy and feminist critiques of individual subject, but also inherits key elements of the poststructural critique of psychoanalysis, accused by Deleuze and Guattari of being a theory of separation rather than an analysis of the unconscious. ${ }^{30}$ In their critique of the Oedipal Triangle (maman-papa-moi) lies a larger critique of a subject formed in separation rather than in context. Deleuze and Guattari emphasize the influence external political, social, cultural and economic factors have on individual development. They argue that the Dreyfuss Affair, Vietnam War and other political conflicts have as much influence on individuals as whatever the mother and father do to their child. These critiques of individualism (as ontology) support the claim of always already social character of art and efforts to limit it, thus suggesting, that the notion of counterpublics is perhaps a good solution also of the problem of the very ontology of censorship. The individualism of censorship and other limitations of artistic production is a legal necessity, perhaps, however in cultural theory of art it should perhaps be replaced by a social, collective perspective.

One of the ways, in which the social and collective dimensions of art and theatre are perhaps most pertinent, are the moments when cultural producers function as workers (which - some claim - is their permanent position). The economy plays the role of an eminence grise in almost all artistic work produced today, being completely exempt of any public social control in cases of private funders, or only vaguely controlled in case of public funding, which is still the main source of cultural funding in most EU countries. The anti-censorship agencies in Poland, as exemplified, for instance, by the initiative Indeks 73 , became to a large extent agencies defending the workers' rights of artists and an agency for social control over public funding (see initiatives such as: Indeks 73, Obywatelskie Forum Sztuki Współczesnej or cultural sections of the labour union Inicjatywa Pracownicza).

Critical reviews of the ways art funding was organized and distributed has influenced the local and central authorities making them willing to show more transparency and participation in their decision making. The concept of "economic censorship", put forward by Hans Haacke and Pierre Bourdieu in their conversation published under the title Free Exchange, later expanded by Robert Atkins and Svetlana Mintcheva in Censoring Culture, and also advanced by Lisa Duggan in Twilight of Equality?, show how today's artistic production is in many ways determined by funding, its expansion and/ or limitations. ${ }^{31}$ "Economic censorship" usually takes place at the in-

29 See: I. Lorey, op. cit. and G. Raunig, Dividuum: Machinic Capitalism and Molecular Revolution, transl. by A. Derieg, Semiotext(e), Los Angeles 2015.

30 G. Deleuze, F. Guattari, Anti-Oedipe, Éditions du Minuit, Paris 1972.

31 P. Bourdieu, H. Haacke, Free Exchange, Polity Press, Cambridge 1995; S. Mintcheva, The Censor Within, in: R. Atkins, S. Mintcheva (eds.), Censoring Culture: Contemporary Threats to Free Expression, The New Press, New York-London 2006; L. Duggan, Twilight of Equality: Neoliberalism, 
tersection of several factors. For example the case of Nieznalska was triggered by the supposed "harm on religious feelings," but it involved economic factors, as it is risky for an institution to invite an artist facing criminal trial and alienate state sponsors as well as private donors.

Since 1989, some 200 cases of art censorship have happened in Poland, some based on protection of religious values, some - on protecting the children, some resulting of public offense, copyright violations or economic exclusion..$^{32}$ As it was argued by Izabela Kowalczyk and numerous other authors, the majority of censorship cases in Poland are initiated by conservative politicians, activists or members of the clergy. Interestingly, most of these cases caused resistance, sometimes leading to even more success on the side of the authors of the censored pieces, and always producing a public debate, sometimes or several years, concerning the role of art, its producers and institutions as well, as values at the core of the society. Most of these cases were also largely discussed in public - by media, activists, artists, sometimes becoming famous cases and leading to public protests. In the course of these controversies the artistic freedom was either defended or even expanded.

There are however other forms of resistance and counterpublics in the recent years in Poland. The actions of the Obywatelskie Forum Sztuki Współczesnej (Public Forum of Contemporary Art), sometimes supported by the labor union Inicjatywa Pracownicza (Worker's Initiative), consist in resisting to exploitation of artists and other workers in the field of culture - protests against abuse, economic injustices or other violations of the workers status. The actions take the classical forms of protest, petitions, legal advice and media actions, sometimes leading to success. The Forum also conducted negotiations with major Polish state run galleries concerning the minimal honorary for any exhibited art work and the end of the practice of showing art without a fee for the artists. Speaking of artists and other workers in culture as of workers, emphasizing our rights as laborers/producers, can also be seen as allowing an invisible minority articulation. The mainstream perception of those involved in art field is that being a culturally privileged group, it is also privileged economically, and since gentlemen "don't discuss money" (a popular idiom in Poland), thus also salaries and fees should remind invisible. Also the general atmosphere surrounding discussions on labour and workers rights has not been very good in Poland in the decades after 1989, which seems paradoxical at least for two reasons: it was the actions of the union ("Solidarność"), that led to the introduction of capitalism in Poland and thus the right to belong to workers unions is a constitutional right. However - it took a long legal battle to also include those not working on full time contracts in this constitutionally granted privilege. This might explain at least some complexity the workers rights met in Poland. Now - the majority of artists are already less suspicious

Cultural Politics, and the Attack on Democracy, Beacon Press, Boston 2003; E. Majewska, Sztuka jako...

32 See: I. Kowalczyk, Ciało i władza. Polska sztuka krytyczna lat 90., Wydawnictwo Sic!, Warszawa 2002; E. Majewska, Sztuka jako... 
of discussing the honoraries and fees, however - it required an Artists Strike in 2009 and a plethora of other actions, which should be counted as counterpublics, and rather proletarian, than bourgeois ones, to become true.

The protest was also a major form of action of "Żubrzyce" (the (she)Bisons), whowearing the masks of Bisons, somewhat similarly to the American Group Guerilla Girls, entered the Center of Contemporary Art and National Museum in Warsaw, and several other venues, demanding better working conditions for artists and other workers, more women's work in collections and better handling of the issues of gender and social exclusion in the years 2016-2018. The (she)Bisons [Żubrzyce] always held slogans, and their actions usually brought some invisible issues to light. They definitely could not be counted in the liberal "public sphere", as Habermas and earlier political theorists have it, as they undermined and criticized not only particular decisions of central and local policy makers, including the Minister of Culture, the directors of several Warsaw based public art galleries and the Art Academy, but also the cultural and economic exclusion of women granted in their forced delegation to the private sphere. The actions of the (she)Bisons group fuel the feminist artistic counterpublics. Their actions, voicing disagreement and contesting the private/public divide, as well as allowing the debate on common issues - are functions of feminist counterpublics, enumerated by Fraser.

Resistance is part of the world of cultural production, and it is often - inadvertently - fostered by the state or the clergy trying to impose limitations. The massive involvement in the process of staging Golgota Picnic in all kinds of venues in response to the ban in 2014 and 2015 was clearly an indication that in this case large masses of the population decided to engage in a case that normally would only interest a small minority of cultural producers. The almost obscene capitulation of the director of the Malta Festival, combined with many people's genuine fascination with Garcia's provocative text was what made the popular resistance to the ban possible, enabling a truly impressive counterpublic agency. Also the artistic development of Dorota Nieznalska, who transformed the pain caused by her accusers into a deep analysis of violence in her artwork and whose case became the focus of the 2003 women's demonstration and of anti-censorship networks such as Indeks 73, shows that art can work as counterpublics, uniting people opposing both the existing authorities and the socio-cultural norms oppressing minorities.

Art is an interesting field, because the forms of debate it offers is at the same time its labour. While in case of house workers, factory workers and other laborers it is rather easy to divide their work from their expressions of dissent, in case of artists art can be or sometimes is their dissent. This makes art perhaps best suited to allow counterpublics. Seen in this perspective, artistic resistance presents itself as the often unpleasant, or even painful element of the social, a norm rather than an exception. As Foucault and Butler have argued, norms imply a system of violence of which only the most visible part is solely symbolic. Acts of physical violence reacting to forms of gender insubordination are structurally similar to acts of censorship, which range 
from the more subtle, yet often painful ones, such as withdrawal of funding, lack of further exhibitions, etc., down to the death penalty, physical violence or deportation. As I argued above, such resistance, although often experienced as solitary, individual agency, should perhaps be seen as a vital and collective part of the social, initiating debates, creative acts and solidarity among cultural producers, their public and the general public as well.

Some acts of censorship have been done in the name of the common good, peace or safety. If culture is the space where, as Hegel claimed, the subject meets themselves as "other", we need to ask whether there is and ever was a non-conflicted culture? And furthermore: isn't it by definition, that artistic experience causes estrangement, or perhaps: that it functions by mode of estrangement? And thus its perception and reception, as well as production, are a social experience?

Perhaps art is, as Adorno and Rancière suggested in their very different ways, a zone of dissent par excellence? Although many pieces merely mirror various forms of resistance, copying or even plagiarizing the original efforts of some dissenting others, be it artists, workers, activists or subalterns spotted in exotic territories, still the main tendency remains an important part of the public sphere, subsuming the necessary function of articulating the needs and demands of those condemned to invisibility. While a critique or even opposition to some parts of artistic production seems necessary, it can also be seen, that the art field provides multiple forms of counterpublics, particularly at times, when it resists.

As this article shows, several artistic events and projects have mobilized the general public to debate by means of resisting - against censorship, inequalities, exclusions, marginalization, sexism or other bias. The forms of resistance discussed here clearly evolve towards the non-heroic, ordinary and weak, focusing on persistence and subversion or weak universal connections rather, than on the typical macho heroic agency, known from the past. Because of such shifts in its practice, art becomes particularly important not only as a form of dissent, but also as a form of public spheres - those of the excluded and marginalized - counterpublics. And in this role resistance, under its multifold forms and demands - becomes a practice of alternative, while voicing dissent or performing it, also creates the communities, collectives or publics, where disagreement and demands are made.

\section{Bibliography}

Adamiecka-Sitek A., Kurz I. (eds.), Piknik Golgota Polska. Sztuka - religia - demokracja, Wydawnictwo Krytyki Politycznej, Warszawa 2015.

Araszkiewicz A., Sprawa Nieznalskiej a proces Gorgonowej, “Obieg Art Magazine” 2006, http://archiwum-obieg.u-jazdowski.pl/teksty/5848 (accessed 24.04.2018).

Bourdieu P., Haacke H., Free Exchange, Polity Press, Cambridge 1995.

Butler J., Excitable Speech, Routledge, London-New York 1997.

Deleuze G., Guattari F., Anti-Oedipe, Éditions du Minuit, Paris 1972. 
Deutsche R., Art and Public Space: Questions of Democracy, "Social Text” 1992, no. 33, pp. 34-53.

Diderot D., Paradoxe sur le comédien, Hermann, Paris 1996.

Duggan L., Twilight of Equality: Neoliberalism, Cultural Politics, and the Attack on Democracy, Beacon Press, Boston 2003.

Guattari F., Three Ecologies, Continuum, London 2000.

Foucault M., Discipline and Punish: The Birth of the Prison, Vintage Books - Random House, New York 1995.

Fraser N., Rethinking the Public Sphere: A Contribution to the Critique of Actually Existing Democracy, "Social Text" 1990, no. 25/26.

Habermas J., Structural Transformation of the Public Sphere, MIT Press, Cambridge, MA 1990.

Honig B., Antigone, Interrupted, Cambridge University Press, Cambridge 2013.

Karaś D., Idealny krem z ludzkiego tluszczu, “Gazeta Wyborcza”, 6.03.2009, http://wyborcza. pl/1,75398,6350018,Idealny_krem_z_ludzkiego_tluszczu.html (accessed 27.05.2019).

Kluge A., Negt O., Public Sphere and Experience, Verso, London [1972] 2016.

Kowalczyk I., Ciało i władza. Polska sztuka krytyczna lat 90., Wydawnictwo Sic!, Warszawa 2002.

Kowalczyk I., Uroki władzy. O władzy rozproszonej, ideologii i widzeniu, Galeria Miejska Arsenał, Poznań 2009.

Kulik Z. in conversation with E. Majewska, System Pionków, "Tygodnik Powszechny” 2009, no. 36 .

Lorey I., State of Insecurity, transl. by A. Derieg, Verso, London 2015.

Majewska E., Kontrpubliczności ludowe i feministyczne. Wczesna "Solidarność" i Czarne Protesty, IWKiP, Warszawa 2018.

Majewska E., Sztuka jako pozór? Cenzura i inne paradoksy upolitycznienia kultury, Korporacja Ha!art, Kraków 2013.

Mintcheva S., The Censor Within, in: R. Atkins, S. Mintcheva (eds.), Censoring Culture: Contemporary Threats to Free Expression, The New Press, New York-London 2006.

Pateman C., The Disorder of Women, Polity Press, Cambridge 1989.

Rancière J., The Politics of Aesthetics: The Division of the Sensible, transl. by G. Rockhill, Continuum, London 2004.

Raunig G., Dividuum: Machinic Capitalism and Molecular Revolution, transl. by A. Derieg, Semiotext(e), Los Angeles 2015.

Rudziński Ł., Skandal w Łaźni, czyli o pokazie, który się nie odbyt, in: Trójmiasto.pl, 10.03.2009, https://kultura.trojmiasto.pl/Skandal-w-Lazni-czyli-o-pokazie-ktory-sie-nie-odbyl-n31925.html (accessed 25.05.2019).

Szreder K., ABC Projektariatu, Fundacja Bęc Zmiana, Warszawa 2015. 